\title{
Diana B. Tyson, A Royal Itinerary - The Journey of Edward I to Scotland in 1296
}

\section{G. Matteo Roccati}

\section{(2) OpenEdition}

10 Journals

\section{Édition électronique}

URL : http://journals.openedition.org/studifrancesi/34301

DOI : 10.4000/studifrancesi.34301

ISSN : 2421-5856

Éditeur

Rosenberg \& Sellier

\section{Édition imprimée}

Date de publication : 1 novembre 2005

Pagination : 389

ISSN : 0039-2944

\section{Référence électronique}

G. Matteo Roccati, «Diana B. Tyson, A Royal Itinerary - The Journey of Edward I to Scotland in 1296 », Studi Francesi [En ligne], 146 (XLIX | II) | 2005, mis en ligne le 30 novembre 2015, consulté le 22 avril 2021. URL : http://journals.openedition.org/studifrancesi/34301 ; DOI : https://doi.org/10.4000/ studifrancesi.34301

Ce document a été généré automatiquement le 22 avril 2021.

\section{(c)}

Studi Francesi è distribuita con Licenza Creative Commons Attribuzione - Non commerciale - Non opere derivate 4.0 Internazionale. 


\title{
Diana B. Tyson, A Royal Itinerary - The Journey of Edward I to Scotland in 1296
}

\author{
G. Matteo Roccati
}

\section{RÉFÉRENCE}

DIANA B. TYSON, A Royal Itinerary - The Journey of Edward I to Scotland in 1296, "Nottingham Medieval Studies", XLV, 2001, pp. 127-144.

1 Ce récit de la campagne d'Ecosse de 1296 existe dans une version anglo-normande (sept manuscrits, dont trois seulement étaient connus jusqu'à présent) et une traduction anglaise plus tardive. On trouvera dans l'article la présentation du texte et de la tradition, ainsi que l'édition établie d'après le ms. London, B.L. Add. 32097, collationné sur les autres témoins. 